\title{
The Effect of Daily Light Integral on Floral Initiation of Pelargonium xdomesticum L.H. Bailey
}

Marietta M. Loehrlein ${ }^{1}$ and Richard Craig ${ }^{2}$

Department of Horticulture, The Pennsylvania State University, University Park, PA 16802

Additional index words. regal Pelargonium, regals, daily light integral, cumulative irradiance

Abstract. Nine cultivars of Pelargonium $\times$ domesticum L.H. Bailey were evaluated for the effect of daily light integral on floral initiation. Plants were grown at four daily light integrals: $5,10,15$, or $20 \mathrm{~mol} \cdot \mathrm{m}^{-2} \cdot \mathrm{d}^{-1}$ for a 16 -hour photoperiod in environmental growth chambers at constant $15.5^{\circ} \mathrm{C}$. Meristems were examined at $50 \mathrm{~mol} \cdot \mathrm{m}^{-2}$ intervals for morphological changes associated with floral initiation. Two phenotypes were identified, cultivars with an association between floral initiation and cumulative irradiance and those with association between floral initiation and chronological time. Genotypic variation was observed among the irradiance-associated phenotypes.

Pelargonium $\times$ domesticum, or the regal Pelargonium is used as a flowering potted plant. Regals are typically marketed for Valentine's Day, Easter, and Mother's Day. Commercial production of regals is limited due to several horticultural problems. The most important of these are whitefly susceptibility, limited postproduction endurance, and the lack of precise cultural protocols for flowering.

Pastresearch has suggested that development of visible floral buds in Pelargonium $\times$ domesticum was controlled by temperatures below $15{ }^{\circ} \mathrm{C}$ (Bohmer and Escher, 1986; Crossley, 1968; Pearson, et al., 1996; Post, 1949), high irradiance, and cumulative irradiance (Craig and Oglevee, 1990; Hackett and Kister, 1974; Nilsen, 1975). Increased irradiance may partially compensate for the negative effects of temperatures above $15^{\circ} \mathrm{C}$ (Hackett and Kister, 1974; Nilsen, 1975). Genotypic variation has been observed for the response to temperature (Bohmer and Escher, 1986; Pearson, et al., 1996) and irradiance (Hackett and Kister, 1974). However, recent research (Loehrlein, 1997) demonstrated that some contemporary regal cultivars initiated floral meristems at temperatures $>15^{\circ} \mathrm{C}$. Nine cultivars were grown at a daily light integral of $10 \mathrm{~mol} \cdot \mathrm{m}^{-2} \cdot \mathrm{d}^{-1}$ at $24 / 18{ }^{\circ} \mathrm{C}$ (day/night) and all cultivars except one ('Majestic') initiated floral meristems at this temperature regime. A

Received for publication 11 Feb. 2003. Accepted for publication 19 June 2003. This work was supported in part by funding from the Fred C. Gloeckner Foundation and The Pennsylvania State University Intercollege Graduate Program in Genetics. We would especially like to thank Oglevee, Ltd., Connellsville, $\mathrm{Pa}$. for providing plant material. We express gratitude to Angelica Zhigilei and Ken Myers for technical support. From a dissertation submitted by the senior author in partial fulfillment of the requirements for the $\mathrm{PhD}$ degree in genetics.

${ }^{1}$ Associate professor of horticulture, Department of Agriculture, Western Illinois University, Macomb, IL 61455.

${ }^{2}$ J. Franklin Styer professor emeritus of horticultural botany, Department of Horticulture, The Pennsylvania State University, University Park, PA 16802.

HortScience Vol. 39(3) June 2004 genotype-dependent response to cumulative irradiance was observed.

Hanniford (1985) observed cellular and morphological changes that occurred in the $P$. $\times$ hortorum meristem during the transition from a vegetative to a floral state. Using two seed-propagated inbreds with different irradiance requirements for flowering, he determined that irradiance was more important during the process of floral initiation than during successive stages of floral development. Armitage et al. (1981) observed, in a seed-propagated $F_{1}$ hybrid geranium $(P . \times$ hortorum $)$, that irradiance was more important during the process of floral initiation, while temperature was more important during floral development.

In $P . \times$ domesticum, $\mathrm{F}_{1}$ hybrids are not practical to obtain due to their complex genetic makeup. They are polyploids derived from interspecific hybridization. Therefore the practical means of commercial propagation is vegetative reproduction. Nevertheless, a paradigm similar to the one influencing $P$. Xhortorum is thought to occur in some of the contemporary cultivars of vegetatively propagated $P$. $\times$ domesticum. Following induction and evocation, the flowering process in $P$. $\times$ domesticum may be divided into two phases: floral initiation and floral development (Loehrlein and Craig, 2000). Both are controlled by environmental and genetic factors. Within a temperature range of $\approx 10$ to $15^{\circ} \mathrm{C}$, floral initiation appears to be primarily affected by cumulative irradiance (Craig and Oglevee, 1990). If floral initiation is controlled by cumulative irradiance, it should be possible to either delay or accelerate its occurrence by manipulating daily light integrals (White and Warrington, 1988).

The objectives of this study were to examine the effects of four daily light integrals on floral initiation to determine whether there is a minimum daily light integral at which floral initiation is prevented in regal cultivars and, further, to discern whether an increase in daily light integral could effectively decrease the time required for floral initiation to occur.
Plant materials and culture. Nine cultivars were selected for this study: 'Baron', 'Duchess', and 'Princess', developed by Ernest Walters in England; 'Erin', 'Jane', and 'Jennifer', developed by David Lemon in California; and 'Fantasy', 'Majestic', and 'Splendor', developed at The Pennsylvania State University by Richard Craig. Propagules were obtained from a culture- and virus-indexed mother block maintained in a greenhouse at Oglevee, Ltd. Connellsville, Pa. One-hundred propagules of each cultivar were rooted in a specially formulated peat-polymer medium (Rubber Dirt; Oglevee, Ltd., Connellsville, Pa.) in 20unit styrofoam liner strips. They were placed under mist with the temperature set at 15.5 ${ }^{\circ} \mathrm{C}$ and provided with $157 \mu \mathrm{mol} \cdot \mathrm{m}^{-2} \cdot \mathrm{s}^{-1}$ of irradiance for a $16-\mathrm{h}$ photoperiod. Liner strips were placed on heated benches to provide a root temperature of $20^{\circ} \mathrm{C}$

Ten-day-old liners were delivered to University Park for the first replication, while 28-d-old liners were delivered for the second replication. Plants received for the first replication were provided an additional 14-d root establishment period after delivery to the University Park campus (Table 1). For root-establishment Styrofoam liner strips containing the plants were placed into flats, which had a double layer of dampened newspaper in the bottom to prevent desiccation. Flats were covered with a plastic dome lid to maintain a humid environment near the leaf surface and were placed into two environmental growth chambers (model GC15; Environmental Growth Chambers, Chagrin Falls, Ohio) Temperature was set at $15.5^{\circ} \mathrm{C}$ with a relative humidity of $60 \%$. Plants were provided a daily light integral of $10 \mathrm{~mol} \cdot \mathrm{m}^{-2} \cdot \mathrm{d}^{-1}$ over a $16-\mathrm{h}$ photoperiod. Sixteen cool-white, high-output 160-W fluorescent lamps (F72T12CWHO; Kloninklije Philips Electronics, N.V., Eindhoven, The Netherlands) provided the irradiance. Ten percent of the input wattage was provided by $60-\mathrm{W}$ incandescent (Philips 60-W 130-V) lamps. Liners were watered as needed with tap water.

Plants received for the first replication were well-rooted, except for 'Baron' and 'Erin'. Data were collected on these cultivars with the understanding that poor root establishment could adversely affect floral initiation. Plants received for the second replication had sufficiently developed roots and therefore did not require additional time for root establishment. However, due to an inadequate number of experimental units of some cultivars, a few nonrooted cuttings were included in the experiment to provide enough experimental units for all sampling times. These nonrooted cuttings were placed into separate cell-packs within the flat, and meristems were not collected from them until the last two sample collection times to allow longer time for root establishment.

In the first replication, the plants were transplanted at the end of the root establishment period. They were $24 \mathrm{~d}$ old. In the second replication plants were transplanted the day 
Crop Production

Table 1. Propagation environment, growth environment and schedule for the nine Pelargonium $\times$ domesticum cultivars evaluated in this study.

\begin{tabular}{|c|c|c|c|c|c|}
\hline & $\begin{array}{l}\text { Propagation } \\
\text { environment }^{2}\end{array}$ & $\begin{array}{c}\text { Growth } \\
\text { chamber } \\
\text { environment }\end{array}$ & $\begin{array}{l}\text { Cuttings } \\
\text { transplanted }\end{array}$ & $\begin{array}{l}\text { Shoot tip } \\
\text { removaly }^{y}\end{array}$ & $\begin{array}{l}\text { Post-shoot-tip } \\
\text { removal }^{\mathrm{x}}\end{array}$ \\
\hline \multicolumn{6}{|l|}{$\overline{\text { Replication } 1}$} \\
\hline Temperature $\left({ }^{\circ} \mathrm{C}\right)$ & 16.6 Night & 15.5 & 15.5 & 15.5 & --- \\
\hline Irradiance & $157 \mu \mathrm{mol} \cdot \mathrm{m}^{-2} \cdot \mathrm{s}^{-1}$ (supplemental) & $10 \mathrm{~mol} \cdot \mathrm{m}^{-2} \cdot \mathrm{d}^{-1}$ & 4 Treatments & 4 Treatments & --- \\
\hline \multicolumn{6}{|l|}{ Replication 2} \\
\hline Date & 4 Sept. 1996 & 2 Oct. 1996 & 3 Oct. 1996 & 4 Oct. 1996 & 11 Oct. 1996 \\
\hline
\end{tabular}

${ }^{2}$ Natural daylength in greenhouse at Oglevee, Ltd., Connellsville, Pa.

${ }^{y}$ Removal of the terminal $5 \mathrm{~mm}$ of tissue from all shoots.

${ }^{\mathrm{x}} \mathrm{A} 7-\mathrm{d}$ meristem reestablishment period was provided with the following conditions: daily light integral of $10 \mathrm{~mol} \cdot \mathrm{m}^{-2} \cdot \mathrm{d}^{-1}$, a $16-\mathrm{h}$ photoperiod and temperature of $15{ }^{\circ} \mathrm{C}$.

following their arrival at University Park. They were 29 d old. Premier Pro-Mix BX, general purpose growing medium (Premier Horticulture, Inc. Red Hill, Pa.), pH 6.0, was steam pasteurized for $1 \mathrm{~h}$, then allowed to cool. In both replications the prerooted liners were transplanted into 2401-L cellpacks from Kord Products Ltd. (Bramalea, Ontario, Canada) containing the pasteurized medium. Six flats containing 20 plants per cultivar were placed in each chamber. Plants were irrigated as needed using $0.66 \mathrm{~g} \cdot \mathrm{L}^{-1}(100 \mathrm{ppm} \mathrm{N})$ Excel 15-2.2-12.5 Cal-Mag water-soluble fertilizer (Scotts-Sierra Horticultural Products, Marysville, Ohio). Once a week liners were irrigated with tap water to leach accumulated salts.

Irradiance treatments. Irradiance treatments were established in four environmental growth chambers (model GC15; Environmental Growth Chambers). Each chamber provided one of four daily light integrals: $5,10,15$, or 20 $\mathrm{mol} \cdot \mathrm{m}^{-2} \cdot \mathrm{d}^{-1}$, within a $16-\mathrm{h}$ photoperiod and 8 -h nyctoperiod. Temperatures were maintained at $15.5^{\circ} \mathrm{C}$.

Irradiance measurements of photosynthetic photon flux density (PPFD) were made using a light meter (LI-185; LI-COR, Lincoln, Neb.) fitted with a quantum sensor. Measurements were made at six positions in the chamber, corresponding to the placement of the six flats of plants. The average irradiance for the chamber was then calculated. Flats were rotated daily within the chamber so that plants received the average irradiance over a 6-d period. Plants were arranged in a completely randomized design.

Shoot tip removal. In replication $1,24 \mathrm{~d}$ following propagation of the experimental units, the terminal $5 \mathrm{~mm}$ of tissue was removed from both apical and axillary shoots to synchronize growth of subsequent meristems. Plants were then placed into the four irradiance treatments. In replication 2, shoot tips were removed 30 $\mathrm{d}$ after propagation and then the plants were placed into a uniform environment for $7 \mathrm{~d}$. Daily light integral was $10 \mathrm{~mol} \cdot \mathrm{m}^{-2} \cdot \mathrm{d}^{-1}$ over a 16-h photoperiod and temperature was set at $15.5^{\circ} \mathrm{C}$. The plants were then placed into the four daily light integrals. Since these plants received an additional $70 \mathrm{~mol} \cdot \mathrm{m}^{-2}$ of irradiance when compared to the first replication, this was added to the total cumulative moles when analyzing floral initiation with respect to cumulative irradiance.

Meristem sampling. For replication 1, successive meristem samples were collected at intervals of $50 \mathrm{~mol} \cdot \mathrm{m}^{-2}$ of cumulative irradiance until a total of $350 \mathrm{~mol} \cdot \mathrm{m}^{-2}$ had been applied within a given chamber (treatment). For the second replication, sample collection at $50-\mathrm{mol} \cdot \mathrm{m}^{-2}$ intervals began after the $7 \mathrm{~d}(10$ $\left.\mathrm{mol} \cdot \mathrm{d}^{-1}\right)$ meristem reestablishment period. For both replications, two to three samples of each cultivar were collected at each sampling time and placed into a freshly prepared fixative of 1 formalin : 0.5 propionic acid : $7100 \%$ ethanol $: 1.5$ distilled water. Tissue was fixed overnight, then transferred to $70 \%$ ethanol for storage.

Nondestructive growth rate measurements. To examine the growth of plants over the length of the experimental period, a nondestructive method of plant growth, the plastochron index, was used (Erickson and Michelini, 1957).

Destructive growth rate measurements. At the time of meristem collection the following growth parameters were recorded: leaf area, number of nodes, number of visible axillary buds ( $\geq 1 \mathrm{~mm}$ long, in the axil of a subapical node on the main stem of the plant), and shoot dry weight.

Statistical analysis. Chi-square $\left(\chi^{2}\right)$ contingency tests (Steel and Torrie, 1960) were performed to evaluate the association between cumulative irradiance and the reproductive state of the meristem. The two response classes were vegetative and florally initiated. For the test of independence, cumulative irradiance was the independent variable and response class was the dependent variable. A chi-square value and an associated probability were calculated from these data. The null hypothesis stated that floral initiation is not dependent on cumulative irradiance. A significant chi-square value $(p \leq 0.05)$ indicated that floral initiation was dependent on cumulative irradiance.

Chi-square contingency tables were constructed and data were analyzed to test for independence of floral initiation and each plant growth parameter. Plant growth parameters were the independent variables and response class of the meristem was the dependent variable.

\section{Results and Discussion}

Effect of minimal daily light integral on floral initiation. The first objective of this research was to determine whether there was a minimum daily light integral at which floral initiation was prevented in regal cultivars.
Eight cultivars initiated floral meristems at 5 $\mathrm{mol} \cdot \mathrm{m}^{-2} \cdot \mathrm{d}^{-1}$. Only 'Majestic' failed to initiate floral meristems throughout the experiment, regardless of daily light integral. If floral initiation in 'Majestic' is a response to cumulative irradiance, then it is clear that $>350 \mathrm{~mol} \cdot \mathrm{m}^{-2}$ are required. If floral initiation in 'Majestic' is a response to chronological time, one would have expected it to occur at the $5 \mathrm{~mol} \cdot \mathrm{m}^{-2} \cdot \mathrm{d}^{-1}$ treatment, which continued for $70 \mathrm{~d}$.

Preliminary observations were made in a separate experiment in which 'Majestic' was grown at two daily light integrals -7 and $14 \mathrm{~mol} \cdot \mathrm{m}^{-2} \cdot \mathrm{d}^{-1}$ - for a $16-\mathrm{h}$ photoperiod. Temperature was set at $14 / 12{ }^{\circ} \mathrm{C}$ day/night. Visible floral buds $(5 \mathrm{~mm})$ developed in both treatments. Visible bud development required $38 \mathrm{~d}$, regardless of daily light integral. These results have three implications: that 'Majestic' may require a daily light integral of at least 7 $\mathrm{mol} \cdot \mathrm{m}^{-2} \cdot \mathrm{d}^{-1}$ for visible bud development; that development of visible buds may not occur in 'Majestic' at temperatures $>14^{\circ} \mathrm{C}$; and/or that development of visible buds in 'Majestic' is a response to chronological time at some specific temperature-irradiance regime.

Effect of shoot-tip removal on floral initiation. The purpose of removing meristems was to synchronize all cuttings with respect to floral initiation treatments. Thus, plants that had developed floral meristems before commencement of the experimental conditions would be forced to produce new meristems under the experimental conditions. The underlying assumption was that floral initiation was a condition restricted to the meristem. Thus, removal of the meristem was expected to result in vegetative axillary shoots.

At the time shoot tips were removed on replication 1 plants, some visible floral buds were noted on the excised tips. In this replication, plants with visible floral buds were tracked. While some meristems were florally initiated at the commencement of the experiment, later observations of the meristems from these plants indicated that they were not always florally initiated (data not shown). This suggests that floral initiation was not necessarily the condition of the plant at the commencement of the experiment. In replication 2, all excised shoot tips were examined microscopically for evidence of floral initiation (Table 2).

Effect of daily light integral on time required for floral initiation to occur. The second objective of this experiment was to discern whether 
Table 2. Macroscopic and microscopic observations of shoot tips for visible floral buds (VFB) and additional florally initiated meristems (FIM) (microscopic observation) removed before commencement of the experiment.

\begin{tabular}{lcrcccc}
\hline & \multicolumn{2}{c}{ Replication 1 } & & \multicolumn{3}{c}{ Replication 2 } \\
\cline { 2 - 6 } Cultivar & Total plants & VFB & & Total plants & VFB & FIM \\
\hline Baron & 80 & 44 & 80 & 42 & 28 \\
Duchess & 80 & 5 & 80 & 25 & 13 \\
Erin & 80 & 35 & 80 & 2 & 0 \\
Fantasy & 80 & 6 & 80 & 7 & 0 \\
Jane & 80 & 5 & 80 & 4 & 0 \\
Jennifer & 80 & 0 & 47 & 8 & 0 \\
Majestic & 80 & 1 & 80 & 0 & 0 \\
Princess & 80 & 0 & 80 & 0 & 0 \\
Splendor & 80 & 23 & 72 & 1 & 35 \\
\hline
\end{tabular}

an increase in daily light integral could effectively decrease the time required for floral initiation to occur in regal cultivars. The results indicate that it is possible to decrease the time required for floral initiation in some genotypes, but not in others. Of the nine cultivars evaluated, two patterns emerged: genotypes that required less time to initiate floral meristems when the daily light integral was increased and genotypes that required the same amount of time, whether daily light integral was 5, 10, 15 , or $20 \mathrm{~mol} \cdot \mathrm{m}^{-2} \cdot \mathrm{d}^{-1}$.

Irradiance and floral initiation: Irradiance-associated genotypes. 'Duchess', 'Jennifer', and 'Splendor' responded to cumulative irradiance for floral initiation. Regardless of daily light integral, these cultivars initiated floral meristems when plants were exposed to a given amount of cumulative irradiance rather than chronological time (Table 3).

In 'Duchess', at three of the four daily light integrals $\left(5,15\right.$, and $\left.20 \mathrm{~mol} \cdot \mathrm{m}^{-2} \cdot \mathrm{d}^{-1}\right)$ a significant association was observed between cumulative irradiance at either $200 \mathrm{or} 250 \mathrm{~mol} \cdot \mathrm{m}^{-2}$ and the transition of the meristem from vegetative to reproductive (Table 3 ). The number of days to floral initiation decreased as daily light integral increased. Plants required from $12.5 \mathrm{~d}$ at 20 $\mathrm{mol} \cdot \mathrm{m}^{-2} \cdot \mathrm{d}^{-1}$ to $40 \mathrm{~d}$ at $5 \mathrm{~mol} \cdot \mathrm{m}^{-2} \cdot \mathrm{d}^{-1}$

'Jennifer' plants initiated flowers at 250 to $300 \mathrm{~mol} \cdot \mathrm{m}^{-2}$ cumulative irradiance at each of the four daily light integrals. (Table 3 ). As with 'Duchess', the number of days to floral initiation decreased proportionally as daily light integral increased. However, significance was only found at $5 \mathrm{~mol} \cdot \mathrm{m}^{-2} \cdot \mathrm{d}^{-1}$. This was partially because on many plants the apical meristem initiated florally at various collection times throughout the experiment, while some meristem samples collected late in the experiment were still vegetative. A trend was observed, however, such that at 250 to $300 \mathrm{~mol} \cdot \mathrm{m}^{-2}$ the highest $\chi^{2}$ values were observed. Using these values, the trend was for the number of days required for floral initiation to increase from 12.5 at $20 \mathrm{~mol} \cdot \mathrm{m}^{-2} \cdot \mathrm{d}^{-1}$ to 60 at $5 \mathrm{~mol} \cdot \mathrm{m}^{-2} \cdot \mathrm{d}^{-1}$.

In 'Splendor' a significant association was observed at 5,15 , and $20 \mathrm{~mol} \cdot \mathrm{m}^{-2} \cdot \mathrm{d}^{-1}$, such that between 200 to $250 \mathrm{~mol} \cdot \mathrm{m}^{-2}$ of cumulative irradiance were required for the transition of the meristem from vegetative to reproductive (Table 3 ). The number of days to floral initiation increased from 10 to $40 \mathrm{~d}$ as daily light integral decreased from 20 to 5 $\mathrm{mol} \cdot \mathrm{m}^{-2} \cdot \mathrm{d}^{-1}$ (Table 3$)$. Data for 'Splendor' at $10 \mathrm{~mol} \cdot \mathrm{m}^{-2} \cdot \mathrm{d}^{-1}$ is inconsistent between the two replications, such that when results from both

${ }^{2} 5 \mathrm{~mol} \cdot \mathrm{d}^{-1}$ not analyzed due to failure of floral initiation to occur shown due to failure of floral initiation to occur.
Irradiance and floral initiation: Time-associated genotypes. 'Baron', 'Fantasy', 'Jane' and 'Princess', initiated floral meristems in response to chronological time rather than cumulative irradiance. 'Fantasy', 'Jane', and 'Princess' required $\approx 30 \mathrm{~d}$ for floral initiation, regardless of the daily light integral. 'Baron' required $\approx 17 \mathrm{~d}$ (Table 3 ).

It is helpful to keep in mind that the length of time for $350 \mathrm{~mol}$ to accumulate is different for each daily light integral. The length of the experiment for each treatment varied from $70 \mathrm{~d}$ at $5 \mathrm{~mol} \cdot \mathrm{m}^{-2} \cdot \mathrm{d}^{-1}$, to $35 \mathrm{~d}$ at $10 \mathrm{~mol} \cdot \mathrm{m}^{-2} \cdot \mathrm{d}^{-1}, 23.3 \mathrm{~d}$ at $15 \mathrm{~mol} \cdot \mathrm{m}^{-2} \cdot \mathrm{d}^{-1}$, and $17.5 \mathrm{~d}$ at $20 \mathrm{~mol} \cdot \mathrm{m}^{-2} \cdot \mathrm{d}^{-1}$. In cultivars that appeared to require a certain number of days for floral initiation to occur, some treatments dic not last long enough. For example, $17.5 \mathrm{~d}$ ( 20 $\left.\mathrm{mol} \cdot \mathrm{m}^{-2} \cdot \mathrm{d}^{-1}\right)$ was too short for floral initiation to occur in 'Fantasy', 'Princess', 'Jane', and 'Erin', and $23.3 \mathrm{~d}\left(15 \mathrm{~mol} \cdot \mathrm{m}^{-2} \cdot \mathrm{d}^{-1}\right)$ was barely long enough to allow floral initiation to occur in statistically significant numbers. Since the study was designed to evaluate floral initiation during accumulation of $350 \mathrm{~mol}$ of irradiance, the length of time for meristem collection was not considered. Future research on these cultivars should allow a minimum of $30 \mathrm{~d}$ for these

Table 3. Cumulative irradiance $\left(\mathrm{mol} \cdot \mathrm{m}^{-2}\right)$ and number of days required for initiation of eight Pelargonium $\times$ domesticum cultivars in response to daily light integral (DLI).

\begin{tabular}{|c|c|c|c|c|c|}
\hline Cultivar & DLI & $\begin{array}{l}\text { Cumulative } \\
\text { irradiance }\end{array}$ & $\begin{array}{l}\text { Total } \\
\text { days }\end{array}$ & $\begin{array}{c}\chi^{2} \\
\text { value }\end{array}$ & $p$ \\
\hline \multirow[t]{4}{*}{ Baron } & $5^{z}$ & -- & --- & --- & $\begin{array}{l}Y \\
---\end{array}$ \\
\hline & 10 & 200 & 20 & $8.18^{*}$ & $<0.05$ \\
\hline & 15 & 150 & 10 & $8.11^{*}$ & $<0.05$ \\
\hline & 20 & 320 & 16 & $15.10^{* * *}$ & $<0.01$ \\
\hline \multirow[t]{4}{*}{ Duchess } & 5 & 200 & 40 & $15.71^{* *}$ & $<0.01$ \\
\hline & 10 & 200 & 20 & $11.03^{* *}$ & 0.01 \\
\hline & 15 & 250 & 16.6 & $21.19^{* * *}$ & $<0.001$ \\
\hline & 20 & 250 & 12.5 & $11.79^{* *}$ & 0.01 \\
\hline \multirow[t]{4}{*}{ Erin } & 5 & 220 & 37 & $15^{* *}$ & 0.001 \\
\hline & 10 & 320 & 32 & $2.81^{\mathrm{Ns}}$ & $>0.70$ \\
\hline & 15 & 320 & 23.6 & $8.38^{*}$ & 0.05 \\
\hline & $20^{y}$ & -- & -- & --- & --- \\
\hline \multirow{4}{*}{ Fantasy } & 5 & 150 & 30 & $8.9^{*}$ & 0.05 \\
\hline & 10 & 300 & 30 & $9.74^{*}$ & 0.05 \\
\hline & 15 & 400 & 26.7 & $7.87^{*}$ & 0.05 \\
\hline & $20^{x}$ & --- & --- & --- & --- \\
\hline \multirow[t]{4}{*}{ Jane } & 5 & 150 & 30 & $12.1^{* *}$ & 0.01 \\
\hline & 10 & 250 & 25 & $7.1^{\mathrm{Ns}}$ & $<0.10$ \\
\hline & 15 & 350 & 23.3 & $3.18^{\mathrm{vs}}$ & $<0.50$ \\
\hline & $20^{\mathrm{w}}$ & --- & --- & --- & ---- \\
\hline \multirow[t]{4}{*}{ Jennifer } & 5 & 300 & 60 & $9.91^{*}$ & $<0.05$ \\
\hline & 10 & 300 & 30 & $3.60^{\mathrm{Ns}}$ & $>0.30$ \\
\hline & 15 & 300 & 20 & $6.21^{\mathrm{Ns}}$ & $>0.10$ \\
\hline & 20 & 250 & 12.5 & $1.41^{\mathrm{NS}}$ & $>0.70$ \\
\hline \multirow{4}{*}{ Princess } & 5 & 150 & 30 & $11.32^{* *}$ & 0.01 \\
\hline & 10 & 200 & 20 & $9.91^{*}$ & 0.05 \\
\hline & 15 & 350 & 23.3 & $9.49^{*}$ & 0.05 \\
\hline & $20^{\mathrm{w}}$ & --- & --- & --- & --- \\
\hline \multirow[t]{5}{*}{ Splendor } & 5 & 200 & 40 & $8.84^{*}$ & $<0.05$ \\
\hline & 10 & 250 & 25 & $3.13^{\mathrm{NS}}$ & $>0.50$ \\
\hline & $10^{\mathrm{v}}$ & 200 & 25 & $8.18^{*}$ & $<0.05$ \\
\hline & 15 & 200 & 13.3 & $10.60^{*}$ & $<0.05$ \\
\hline & 20 & 200 & 10 & $9.90^{*}$ & $<0.05$ \\
\hline
\end{tabular}

${ }^{y}$ Data from replication 1 not shown due to lack of florally initiated meristems; data from $20 \mathrm{~mol} \cdot \mathrm{d}^{-1} \mathrm{not}$

${ }^{x}$ Data from replication 1 only because in replication 2 plants failed to initiate floral meristems at 10 and 15 $\mathrm{mol} \cdot \mathrm{d}^{-1} ; 20 \mathrm{~mol} \cdot \mathrm{d}^{-1}$ not analyzed due to failure of floral initiation to occur in either replication.

w $20 \mathrm{~mol} \cdot \mathrm{d}^{-1}$ not analyzed due to failure of floral initiation to occur.

${ }^{\vee}$ Replication 2 only because in replication 1 floral initiation was sporadic throughout the experiment. Ns, ,*,*,****NNonsignificant or significant at $P \leq 0.05,0.01$, or 0.001 , respectively. 
particular cultivars to provide better numbers for statistical analysis.

These results represent a new paradigm for floral initiation in contemporary cultivars of regal geranium. Previously, development of visible floral buds was controlled by temperatures below $15{ }^{\circ} \mathrm{C}$, high irradiance, and cumulative irradiance. In the new paradigm, cumulative irradiance and time are importan factors. 'Baron', 'Fantasy', 'Jane', and 'Princess' may be thought of as time-responsive with respect to floral initiation. Previous results (Loehrlein, 1997) demonstrated that 'Baron', 'Fantasy', and 'Princess' were able to initiate floral meristems at $24 / 18^{\circ} \mathrm{C}$ day/night.

Future breeding efforts should focus on reducing the number of days required for floral initiation in time-responsive cultivars. During development of the Pennsylvania State University cultivars, selection pressure included a floral initiation period of $28 \mathrm{~d}$ at $\approx 12.5$ to $15 \mathrm{~mol} \cdot \mathrm{m}^{-2} \cdot \mathrm{d}^{-1}$. At the time the objective was to select genotypes that developed flowers in response to 350 to $425 \mathrm{~mol} \cdot \mathrm{m}^{-2}$ of cumulative irradiance, applied after the root-establishment period (Craig and Oglevee, 1990). This took $\approx 28 \mathrm{~d}$. And so it appears possible that in 'Fantasy' there was an inadvertent selection pressure applied for floral initiation to occur in $\approx 28 \mathrm{~d}$, regardless of the daily light integral.

Floral initiation and plant growth. The primary purpose for measuring plastochron index, leaf area, number of nodes, number of visible axillary buds, and shoot dry weight and evaluating its association with floral initiation was to determine whether floral initiation was associated with any growth parameters. The assumption was that floral initiation was a response to irradiance, not a function of or a response to the specified plant growth parameters. However, if a plant growth parameter was associated with floral initiation, it could serve as a predictor or indicator of floral initiation.

Associations between floral initiation and plant growth parameters were observed (data not shown), but they were too inconsistent to serve as predictors for floral initiation. The responses varied both by cultivar and by daily light integral. In irradiance-associated cultivars, a trend was observed with respect to plant growth parameters: as daily light integral was increased, floral initiation occurred in plant with less leaf area or dry weight. Among the time-associated cultivars, when plants were grown at $5 \mathrm{~mol} \cdot \mathrm{m}^{-2} \cdot \mathrm{d}^{-1}$, a significant association between plant growth and floral initiation was observed for 'Erin', 'Fantasy', and 'Princess'. Otherwise, the association between a given plant growth parameter and floral initiation was inconsistent. Discriminating values differed depending on daily light integral. This result renders these plant growth parameters inadequate as indicators or predictors of floral initiation.

\section{Summary}

The results of this research provided a more precise understanding of floral initiation in contemporary cultivars of Pelargonium $\times$ domesticum. Previous research suggested that irradiance affected flowering (Hackett and Kister, 1974; Nilsen, 1975; Post, 1942), but previous research was not designed to quantify the irradiance effect on floral initiation. By growing plants under four daily light integrals and observing floral initiation of meristems, more precise information was obtained. From this information two new floral initiation phenotypes emerged: irradiance-responsive floral initiation and time-responsive floral initiation. Cultivars in the latter category appear to remain affected by irradiance, as the number of days required for floral initiation in these cultivars decreased as the daily light integral increased. A third phenotype was nonresponsive ('Majestic'), suggesting that the older paradigm is still at work, where temperatures below 15.5 ${ }^{\circ} \mathrm{F}$ are still required.

The two new floral initiation phenotypes are an important consideration for future breeding. With the objective of improved predictability of the floral initiation response, it is desirable to separate the types into those that respond to cumulative irradiance and those that respond to time. The relatively low irradiance requirement of cultivars like 'Duchess' and 'Splendor' suggest the possibility of developing new genotypes with similar or improved irradiance requirements. Cultivars released in the 'Elegance' series developed at The Pennsylvania State University were originally selected for floral initiation at cumulative irradiance of 350 to $425 \mathrm{~mol} \cdot \mathrm{m}^{-2}$ in a 28 -d period. 'Splendor' was included in this series and is now known to require $\approx 200 \mathrm{~mol}$ of irradiance for floral initiation. It is apparent that progress has been made with respect to decreasing the cumulative irradiance required for floral initiation. The relatively low irradiance requirements of
'Splendor' and 'Duchess' suggest that further decreases may be possible.

'Baron', a time-associated cultivar, had the lowest requirement for number of days for floral initiation. 'Fantasy', 'Jane', and 'Princess' all required $\approx 30 \mathrm{~d}$. Selection pressure to develop cultivars that will initiate flowers in fewer days seems to be a feasible strategy in a breeding program.

\section{Literature Cited}

Armitage, A.M., W.H. Carlson, and J.A. Flore. 1981. The effect of temperature and quantum flux density on the morphology, physiology, and flowering of hybrid geraniums. J. Amer. Soc. Hort. Sci. 106(5):643-647.

Bohmer, U. andF.Escher. 1986.Zeitgemasse produktionsverfahren fur Edelpelargonien. (Timely production procedures for regal Pelargoniums). Gartnerborse und gartenweld.44:1648-1651.

Craig, R. and J.R. Oglevee. 1990. Precision flowering of regal pelargoniums (Pelargonium $\times$ domesticum). Process patent \#4,897,957.

Crossley, J.H. 1968. Warm vs. cool short days as preconditions for flowering of Pelargonium $\times$ domesticum cultivars. Can. J. Plant Sci. 48:211-212.

Erickson, R.O. and F.J. Michelini. 1957. The plastochron index. Amer. J. Bot. 44(4):297-305.

Hackett, W. P. and J. Kister. 1974. Environmental factors affecting flowering in Pelargonium $\times$ domesticum cultivars. J. Amer. Soc. Hort. Sci. 99(1):15-17.

Hanniford, G. 1985. An analysis of the genetic control of early flowering in the geranium Pelargonium xhortorum, L.H. Bailey. PhD diss. Pa. State Univ., University Park.

Loehrlein, M.M. 1997. Floral ontogeny of Pelargonium $\times$ domesticum and response of floral initiation to irradiance. PhD diss. Pa. State Univ., University Park.

Loehrlein, M.M. and R. Craig. 2000. Floral ontogeny of Pelargonium $\times$ domesticum. J.Amer. Soc. Hort. Sci. 125(1):36-40.

Nilsen, J.H. 1975. Factors affecting flowering in regal pelargoniums (Pelargonium $\times$ domesticum Bailey). Acta Hort. 51:299-309.

Pearson, S., L. Sach, and P. Hadley. 1996. Coming in from the cold. Grower (23 May):30-31.

Post, K. 1949. Florist crop production and marketing. Orange Judd, New York.

Steele, R.G.D. and J.H. Torrie. 1960. Principles and procedures of statistics. McGraw-Hill Book Co., New York.

White, J.W. and I.J. Warrington. 1988. Temperature and light integral effects on growth and flowering of hybrid geraniums. J. Amer. Soc. Hort. Sci. 113(3):354-359. 